\title{
Incidence of Household Catastrophic and Impoverishing Health Expenditures among Patients with Breast Cancer in Iran
}

\section{Faranak Ahmadi}

Urmia University of Medical Sciences

Hamidreza Farrokh-Eslamlou

Urmia University of Medical Sciences

Hasan Yusefzadeh

Urmia University of Medical Sciences

Cyrus Alinia ( $\nabla$ siros_alinia@yahoo.com )

Urmia University of Medical Sciences

\section{Research Article}

Keywords: Iran, breast cancer, catastrophic health expenditures, impoverishing health expenditures, outof-pocket

Posted Date: December 10th, 2020

DOl: https://doi.org/10.21203/rs.3.rs-118051/v1

License: (9) This work is licensed under a Creative Commons Attribution 4.0 International License. Read Full License

Version of Record: A version of this preprint was published at BMC Health Services Research on April 9th, 2021. See the published version at https://doi.org/10.1186/s12913-021-06330-6. 


\section{Abstract}

Background: Breast cancer disease is the most common cancer among Iranian women. Management of this disease requires expensive services and care, imposing a significant financial burden on the households. This study calculated out-of-pocket (OOP), catastrophic health expenditure (CHE), and impoverishing health spending attributed to breast cancer in Iran.

Methods: In this cross-sectional household study, clinical and financial information on breast cancer and also household information (expenditures and income) were obtained through face-to-face interviews and completing a questionnaire by 138 women with this disease in 2019. To defining the CHE, we applied three non-food expenditure thresholds of $40 \%, 20 \%$, and $10 \%$. Disease costs included periodical visits, diagnostic services, hospitalization care, treatment and rehabilitation services, home, and informal care. Households were disaggregated into socioeconomic status quintiles based on their monthly consumption expenditures, where SES classifications were standardized by Adult Equivalent values of consumption expenditures. For statistical comparisons of the incidence of $\mathrm{CHE}$ and impoverishing spending, we applied the independent t-test and one-way ANOVA respectively for two and more than two separate subgroups. Besides identifying the factors affecting these indicators, we performed the two different multivariate logistic regression models.

Results: This study finds that each patient had an average OOP payment of \$US 97.87 for the requested services, leading to impoverished of $5.07 \%$ and exposed to CHE of $13.77 \%$ of their households. These indicators have been mainly concentrated among the poor, as they have spent a large part of their meager income on buying the needed services, and for this purpose, most of them have been forced to sell their assets, borrow, or take a bank loan.

Conclusions: Vulnerable people should be supported by expanding insurance coverage, governmental supporting programs, and increasing access to quality and effective public sector services.

\section{Background}

Breast cancer is the most common cancer and is the second leading cause of cancer death among Iranian women and also in the western world [1]. Annually, more than 1.2 million patients are diagnosed with this age-related disease, of which more than 500,000 dies [2]. In other words, one out of every 8 to 10 women in the world and 10 to 15 women in Iran gets breast cancer [3]. The prevalence of breast cancer in Iran has increased dramatically over the past two decades due to lifestyle changes [4] so that Iranian women getting the disease on average a decade earlier than their Western counterparts [5].

Breast cancer is a chronic disease that requires an expensive diagnostic, treatment, and rehabilitation services. In the long run, this disease imposes high costs on the patients, families, and health systems [68]. Management of this disease requires frequent hospitalization courses, receiving specialized laboratory tests, surgery, chemotherapy, radiotherapy, expensive drugs, outpatient visits, and continuous follow-up [9]. The disease, especially in more advanced stages, leads to unemployment and reduced income, 
implying additional economic pressure on the patient and her family [6-8]. This financial pressure will obviously be even more tremendous for vulnerable groups such as poor or unemployed households. [6]

The Iranian health system implemented some policies to reduce out-of-pocket payments to a maximum of $6 \%$ of total costs in the public sector, increasing insurance coverage, and regulating the market to cushion breast cancer patients against the costs [10]. Due to the lack of insurance coverage for some services and needed medicines, as well as receiving part of the services from the private sector, it seems that the health system has not had much success in this field [11].

Although very limited information and documentation are available on the cost of breast cancer management, given the above, this hypothesis arises that households struggling with the disease significantly exposed to catastrophic and impoverishing health expenditures. In this study, we have tried to test this hypothesis and fill this knowledge gap in Iran.

\section{Methods}

\section{Study design and data collection}

In this cross-sectional study, information on breast cancer was obtained through face-to-face interviews and completing a questionnaire by 138 women with this disease in Urmia, Iran, in 2019. This information covered the demographic data of patients and heads of the household, household expenses and income, clinical data on the disease, and funding sources for the disease management. Samples were randomly selected from a list of registered patients in the private and public specialized centers of Urmia University of Medical Sciences. To minimize the number of missed cases, at least three times at two-week intervals, contact was made with any respondent who was not ready for the interview for any reason, and an interview was conducted with her. The inclusion criteria were having at least 25 years of age, passing at least one month since the definitive diagnosis of the disease, and been living in Iran for the past year.

\section{Measuring catastrophic breast cancer expenditures}

If a household is forced to cut their living subsistence over a while due to OOP payments for health care services, the costs are catastrophic. Technically, health expenditure is considered catastrophic when OOP health expenditures exceed a specific household capacity ratio to pay subsistence. This threshold is set by the World Health Organization (WHO) at $40 \%$, but other standards, such as $20 \%$ and $10 \%$, have been introduced in various related studies. Household capacity to pay is obtained by subtracting the average monthly cost of subsistence from the average monthly effective income (total consumption expenditure) of the household over the past year. In other words, the capacity to pay is defined as non-subsistence expenses. Based on the WHO recommendation, we consider subsistence expenses to be equal to household food expenditures. [11] Food expenses make up a large portion of household expenses, have a low income elasticity, and are strongly influenced by household members [12]. Household food expenditures include the costs incurred by the household in purchasing foodstuffs and the financial value of the food products produced and consumed by the household itself. Food expenses incurred by 
households in restaurants and hotels are excluded from these calculations. Using the variable of household expenditures has been that better than income can show the purchasing power of households, especially in developing countries [13]. Given that household expenditures can have an unbalanced distribution during different months of the year, we asked people about the average monthly household expenditure over the past year, which included all of following items; food, beverages, recreation, education services, hotel and restaurant, clothing and footwear, cigarettes and tobacco, house and shop

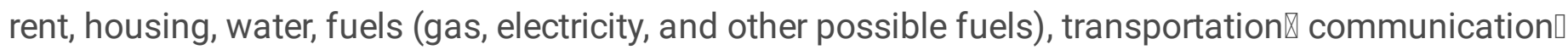

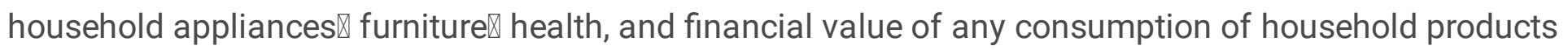
(agricultural, services, industrial, etc.)

To considering the diminishing marginal utility of remained household consumption expenditure after subtracting the Out-of-pocket (OOP) health payment from effective income for different SES quintiles, we used three levels of non-food expenditure thresholds; $10 \%, 20 \%$, and $40 \%$. OOP payments refer to the spending made by households at the point they receive breast cancer services, which cover the periodical visits, diagnostic services, hospitalization care, treatment services (drugs, chemotherapy, radiotherapy, surgery, and others), rehabilitation services, home cares provided by the physician, nurse, and household members, and finally receive informal care from traditional therapists.

\section{Measuring impoverishing due to breast cancer spending}

The impoverishing payment is measured by the proportion of households that falls below the absolute poverty line after breast cancer spending is subtracted from total household consumption [14]. Such households can still not meet their basic food needs, even if they spend all their remaining expenses on them. According to a report by the Iranian Ministry of Labor, the monthly cost of a subsistence basket for each person was 11393940 Rials (84.40 PPP \$US) in 2019 [15]. Therefore, by multiplying this value by the standardized household dimension, each household's absolute poverty line is calculated. If the total household expenditure was less than their equivalent absolute poverty line, that household was considered poor. If the total remaining household expenditure goes below this estimated line due to the cost of treating breast cancer, that household will incur impoverishing spending. Also, we asked the participants the potentially unmet health needs of patients due to the cost of treating breast cancer and the sources of funding for the disease.

\section{Statistical analysis}

Households were disaggregated into SES quintiles based on their monthly consumption expenditures, where SES classifications were standardized by Adult Equivalent (AE) values of consumption expenditures. For this, we applied the formula presented by Cirto and Michael [16] as follow:

$A E=(A+a K) \theta$

Where $\mathrm{A}=$ number of adults (aged over 18 years), $\mathrm{K}=$ number of children, $\mathrm{a}=$ cost coefficient for children, and $\theta=$ degree of economies of scale. The recommended values for $a$ and $\theta$ for developing countries are 
0.4 and 1.0 , respectively [16].

For statistical comparisons of the incidence of catastrophic and impoverishing spending on breast cancer treatment between different sociodemographic subgroups, we applied the independent t-test and one-way ANOVA respectively for two and more than two separate subgroups. In this analysis, the p-values which are equal or below 0.05 are considered to be significant.

To identify the factors affecting on catastrophic and impoverishing health expenditures for breast cancer treatment, we performed the two separate multivariate logistic regression models with the following dependent variables:

- Disease characteristics (cancer type, disease duration, treatment types).

- Patient characteristics (age, educational level, place of living, marital status, insurance status, household size).

- Head of household characteristics (age, educational level, marital status).

Those variables that had multicollinearity problems were omitted from the models. We estimated and reported the odds ratio, $95 \%$ confidence interval $(\mathrm{Cl})$, and p-value statistics for each variable. Normality distribution of the variables was checked by One-Sample Kolmogorov-Smirnov test. All statistical analyses were performed by STATA version 15.0 software (Stata Corp, College Station, TX).

\section{Results}

The findings indicate that the mean age of 138 patients participating in the study was 44.3 years (SD: 11.73), about a third of whom were illiterate and often lived in the urban. Also, more than $97 \%$ of them have at least one type of basic health insurance. (Table 1)

Table 1. Characteristics of the study sample 


\begin{tabular}{|c|c|c|}
\hline \multirow[t]{2}{*}{ Variables } & Head of household & Patient \\
\hline & \multicolumn{2}{|c|}{$\begin{array}{c}\mathrm{N}=138 \\
\text { Frequency (\%) }\end{array}$} \\
\hline Gender (female) & $19(13.77)$ & $138(100)$ \\
\hline Mean of age (SD) & $65.32(13.40)$ & $44.30(11.73)$ \\
\hline \multicolumn{3}{|l|}{ Education level } \\
\hline Illiterate & $34(24.64)$ & $45(32.61)$ \\
\hline Elementary & $31(22.46)$ & $33(23.91)$ \\
\hline Middle school & $10(7.25)$ & $14(10.14)$ \\
\hline Higher school & 40 (28.99) & $35(25.36)$ \\
\hline University & $23(16.67)$ & $11(7.97)$ \\
\hline \multicolumn{3}{|l|}{ Marital status } \\
\hline Single & $4(2.90)$ & $14(10.14)$ \\
\hline Married & $120(86.96)$ & $108(78.26)$ \\
\hline Divorced/Widowed & $14(10.14)$ & $16(11.60)$ \\
\hline \multicolumn{3}{|l|}{ Having basic health insurance } \\
\hline Yes & $134(97.10)$ & $134(97.10)$ \\
\hline \multicolumn{3}{|l|}{ Having complementary insurance } \\
\hline Yes & $37(26.81)$ & $36(26.09)$ \\
\hline No & 101 (73.19) & $102(73.91)$ \\
\hline \multirow{2}{*}{\multicolumn{3}{|c|}{ Mean of household dimension (SD) }} \\
\hline & & Place of living \\
\hline Urban & \multirow{2}{*}{\multicolumn{2}{|c|}{$\begin{array}{l}84(60.87) \\
54(39.13)\end{array}$}} \\
\hline Rural & & \\
\hline
\end{tabular}

Table 2 provides findings on amounts of out-of-pocket payment and the incidence of catastrophe and impoverishment in spending on breast cancer management in different SES quintiles. The results show that Iranian households' average amount to receive diagnostic, treatment and rehabilitation services for breast cancer was \$US 97.87. This amount was obtained for the poorest and richest quintiles at \$US 69.97 and 140.83 , respectively, which their difference was statistically significant. The findings also show that, with a threshold of $40 \%$ of the household's capacity to pay, an average of $13.77 \%$ of the households have suffered from catastrophic health expenditure (CHE) caused by breast cancer. This incidence value is estimated at $27.54 \%$ and $40.58 \%$, respectively, for $20 \%$ and $10 \%$ threshold levels. In this regard, there was no statistically significant difference between SES quantiles in all three models. However, the proportion of households incurring CHE in the first to the fifth quantile was between 1.10-1.61.

The results also show that the cost of managing breast cancer disease causes $18.52 \%$ of households belonging to the first quantile to become poor, compared to zero in households belonging to the fifth quantile. The incidence average of impoverishing expenditure was estimated at 5.07.

Table 2. Brest cancer out-of-pocket, catastrophic, and impoverishment health expenditures by SES quintiles (Monthly data-\$US) 


\begin{tabular}{|c|c|c|c|c|c|c|}
\hline \multirow{2}{*}{\multicolumn{2}{|c|}{ Expenditure indexes }} & \multicolumn{3}{|c|}{$\begin{array}{l}\text { Percent of households with } \\
\text { CHE at different threshold }\end{array}$} & \multirow{2}{*}{$\begin{array}{c}\text { OOP } \\
\text { expenditures } \\
\text { (SD) }\end{array}$} & \multirow{2}{*}{$\begin{array}{c}\text { Percent of } \\
\text { impoverished } \\
\text { households }\end{array}$} \\
\hline & & $40 \%$ & $20 \%$ & $10 \%$ & & \\
\hline \multirow[t]{8}{*}{$\begin{array}{c}\text { SES } \\
\text { Quintiles }\end{array}$} & $\begin{array}{l}\text { Q1 } \\
\text { (poorest) }\end{array}$ & 22.22 & 33.33 & 44.44 & $\begin{array}{c}69.97 \\
(66.95)\end{array}$ & 18.52 \\
\hline & Q2 & 11.11 & 18.52 & 29.63 & $\begin{array}{c}68.70 \\
(53.51)\end{array}$ & 0.00 \\
\hline & Q3 & 11.11 & 25.93 & 33.33 & $\begin{array}{c}82.33 \\
(63.18)\end{array}$ & 3.70 \\
\hline & Q4 & 14.29 & 28.57 & 53.57 & $\begin{array}{c}128.22 \\
(119.52)\end{array}$ & 3.57 \\
\hline & $\begin{array}{l}\text { Q5 } \\
\text { (richest) }\end{array}$ & 10.34 & 31.03 & 41.38 & $\begin{array}{l}140.83 \\
(98.94)\end{array}$ & 0.00 \\
\hline & $\begin{array}{l}\text { All } \\
\text { households }\end{array}$ & 13.77 & 27.54 & 40.58 & $\begin{array}{c}97.87 \\
(89.30)\end{array}$ & 5.07 \\
\hline & $\begin{array}{l}\text { Q1:Q5 } \\
\text { ratio }\end{array}$ & 1.61 & 1.21 & 1.10 & 0.50 & $3.65^{b}$ \\
\hline & $\begin{array}{l}\text { Chi square } \\
\text { for } \\
\text { trend (P- } \\
\text { value) }\end{array}$ & $\begin{array}{c}2.24 \\
(0.69)\end{array}$ & $\begin{array}{c}1.78 \\
(0.78)\end{array}$ & $\begin{array}{c}4.07 \\
(0.40)\end{array}$ & $\begin{array}{c}4.81 \\
(0.001)^{a}\end{array}$ & $13.37(0.01)$ \\
\hline
\end{tabular}

a One-way ANOVA test is used.

$\mathrm{b}$ is the result of first quantile by the average value.

Table 3 depicts the incidence of catastrophic and impoverishing payments caused by breast cancer disease in different socio-economic subgroups. The CHE for benign patients, patients treated with radiotherapy, patients have lived in rural areas, patients belong to the age group of $40-65$, illiterate, and single patients were higher than others. However, this difference was statistically significant only for the type of treatment variable. The incidence of poor households due to breast cancer ranged from zero (for older subgroups, undergraduate, undergoing surgery, and patients without health insurance) to $9.52 \%$ (for radiotherapy treatment) in different socio-demographic subgroups. Of course, there was no statistically significant difference between the subgroups of each socio-demographic group.

Table 3. Household catastrophic health expenditures and impoverished costs of breast cancer among different socio-demographic groups of the patients. 


\begin{tabular}{|c|c|c|c|c|c|c|}
\hline \multirow{2}{*}{\multicolumn{2}{|c|}{ SES subgroups }} & \multirow{3}{*}{$\begin{array}{c}\begin{array}{c}\text { Number } \\
\text { (\%) }\end{array} \\
61 \\
(44.20) \\
\end{array}$} & \multicolumn{3}{|c|}{$\begin{array}{l}\text { Percent of households with } \\
\text { CHE at different thresholds }\end{array}$} & \multirow{2}{*}{$\begin{array}{c}\text { Percent of } \\
\text { impoverished } \\
\text { households }\end{array}$} \\
\hline & & & $40 \%$ & $20 \%$ & $10 \%$ & \\
\hline \multirow[t]{2}{*}{ Cancer type } & Benign & & 18.03 & 32.79 & 42.62 & \\
\hline & Malignant & $\begin{array}{c}77 \\
(55.80)\end{array}$ & 10.39 & 23.38 & 38.96 & 5.19 \\
\hline \multirow[t]{2}{*}{$\begin{array}{l}\text { Disease } \\
\text { duration }\end{array}$} & $<1$ years & $\begin{array}{c}117 \\
(74.78)\end{array}$ & 13.68 & 28.21 & 41.88 & 5.13 \\
\hline & $>1$ years & $\begin{array}{c}21 \\
(25.22)\end{array}$ & 14.29 & 23.81 & 33.33 & 4.76 \\
\hline \multirow[t]{4}{*}{$\begin{array}{l}\text { Treatment } \\
\text { type }{ }^{\dagger \neq}\end{array}$} & Chemotherapy & $\begin{array}{c}61 \\
(44.20)\end{array}$ & 8.20 & 26.23 & 37.70 & 3.28 \\
\hline & Radiotherapy & $5(3.62)$ & 60.00 & 100.00 & 100.00 & 9.52 \\
\hline & Surgery & $\begin{array}{c}42 \\
(30.43)\end{array}$ & 23.81 & 35.71 & 40.48 & 0.00 \\
\hline & Others & $\begin{array}{c}30 \\
(21.74)\end{array}$ & 3.33 & 6.67 & 36.67 & 3.33 \\
\hline \multirow[t]{2}{*}{$\begin{array}{l}\text { Place of } \\
\text { living }\end{array}$} & Urban & $\begin{array}{c}84 \\
(60.87)\end{array}$ & 9.52 & 23.81 & 40.48 & 4.76 \\
\hline & Rural & $\begin{array}{c}54 \\
(39.13)\end{array}$ & 20.37 & 33.33 & 40.74 & 5.56 \\
\hline \multirow[t]{2}{*}{$\begin{array}{l}\text { Household } \\
\text { dimension }\end{array}$} & $<5$ persons & $\begin{array}{c}96 \\
(69.57)\end{array}$ & 14.58 & 29.17 & 40.63 & 4.17 \\
\hline & $>4$ persons & $\begin{array}{c}42 \\
(30.43)\end{array}$ & 11.90 & 23.81 & 40.48 & 7.14 \\
\hline \multirow[t]{3}{*}{ Age } & $<40$ years & $\begin{array}{c}31 \\
(23.31)\end{array}$ & 9.68 & 16.13 & 29.03 & 3.23 \\
\hline & 40-65 years & $\begin{array}{c}95 \\
(71.43)\end{array}$ & 14.74 & 30.53 & 44.21 & 5.26 \\
\hline & $>65$ years & $7(5.26)$ & 0.00 & 14.29 & 28.57 & 0.00 \\
\hline \multirow[t]{2}{*}{$\begin{array}{l}\text { Having } \\
\text { insurance }\end{array}$} & Yes & $\begin{array}{c}134 \\
(97.10)\end{array}$ & 14.18 & 28.36 & 41.04 & 5.22 \\
\hline & No & $4(2.90)$ & 0.00 & 0.00 & 25.00 & 0.00 \\
\hline \multirow[t]{3}{*}{$\begin{array}{l}\text { Education } \\
\text { level }\end{array}$} & Illiterate & $\begin{array}{c}45 \\
(32.61)\end{array}$ & 20.00 & 33.33 & 44.44 & 8.89 \\
\hline & $<$ University & $\begin{array}{c}82 \\
(52.49)\end{array}$ & 12.20 & 24.39 & 36.59 & 3.66 \\
\hline & University & $\begin{array}{c}11 \\
(7.97)\end{array}$ & 0.00 & 27.27 & 54.55 & 0.00 \\
\hline \multirow[t]{2}{*}{$\begin{array}{l}\text { Marital } \\
\text { status }\end{array}$} & Married & $\begin{array}{c}108 \\
(78.26)\end{array}$ & 12.04 & 25.93 & 37.96 & 5.56 \\
\hline & Unmarried & $\begin{array}{c}30 \\
(21.74)\end{array}$ & 20.00 & 33.33 & 50.00 & 3.33 \\
\hline
\end{tabular}

$\dagger$ indicates significant difference for catastrophic health expenditures at $40 \%$ threshold between subgroups

$\ddagger$ indicates significant difference for catastrophic health expenditures at $20 \%$ threshold between subgroups

Table 4 presents our regression results. As the results suggest, if we consider the $40 \%$ as a threshold level, odds of CHE statistically significantly was higher among respondents who have used the radiotherapy (odds ratio: $1.33,95 \% \mathrm{Cl}$ : 1.14-1.52) and were lower for elderly patients (odds ratio: $0.28,95 \% \mathrm{Cl}$ : 0.14 - 
0.62 ) and the patients with university education (odds ratio: $0.27,95 \% \mathrm{Cl}: 0.21-0.33$ ) compared with their reference subgroups. These results are not confirmed in another approach, which considers $10 \%$ as the threshold level. Besides, the findings did not show any statistically significant association between impoverishing breast cancer payments with dependent factors except for the patients who had a university degree (odds ratio: $0.37,95 \% \mathrm{Cl}$ : 0.12-0.66).

Table 4. Determinants of catastrophic and impoverishing health expenditure and: a multivariate logistic regression model. 


\begin{tabular}{|c|c|c|c|c|c|c|c|c|c|c|}
\hline \multirow[t]{3}{*}{ bles } & \multirow{3}{*}{$\begin{array}{l}\text { Reference } \\
\text { subgroup }\end{array}$} & \multicolumn{6}{|c|}{ CHE at different thresholds } & \multirow{2}{*}{\multicolumn{3}{|c|}{$\begin{array}{l}\text { Impoverishing } \\
\text { payments }\end{array}$}} \\
\hline & & \multicolumn{3}{|c|}{$\geq 40 \%$ of $\mathrm{CTP}$} & \multicolumn{3}{|c|}{$\geq 10 \%$ of CTP } & & & \\
\hline & & OR & $\begin{array}{c}95 \% \\
\text { CI }\end{array}$ & $\mathrm{p}$ & OR & $\begin{array}{l}95 \% \\
\mathrm{CI}\end{array}$ & $\mathrm{p}$ & OR & $\begin{array}{c}95 \% \\
\text { CI }\end{array}$ & $\mathrm{p}$ \\
\hline \multicolumn{11}{|c|}{ se characteristics } \\
\hline r type & Benign & 0.64 & $\begin{array}{l}0.24- \\
1.04\end{array}$ & 0.12 & 0.64 & $\begin{array}{l}0.39- \\
1.31\end{array}$ & 0.27 & 0.76 & $\begin{array}{l}0.13- \\
2.63\end{array}$ & 0.77 \\
\hline $\begin{array}{l}\text { se } \\
\text { ion }\end{array}$ & $<1$ years & 0.68 & $\begin{array}{l}0.23- \\
1.13\end{array}$ & 0.60 & 0.58 & $\begin{array}{l}0.29- \\
1.55\end{array}$ & 0.34 & 0.95 & $\begin{array}{l}0.48- \\
2.13\end{array}$ & 0.87 \\
\hline $\begin{array}{l}\text { otherapy } \\
\text { iurgery }\end{array}$ & Chemotherapy & $\begin{array}{l}1.33 \\
1.24\end{array}$ & $\begin{array}{l}1.14- \\
1.52 \\
0.94- \\
1.55\end{array}$ & $\begin{array}{l}0.01 \\
0.13\end{array}$ & $\begin{array}{l}1.26 \\
1.12\end{array}$ & $\begin{array}{l}0.04- \\
1.51 \\
0.85- \\
1.39\end{array}$ & $\begin{array}{l}0.16 \\
0.25\end{array}$ & $\begin{array}{l}1.31 \\
1.18\end{array}$ & $\begin{array}{l}0.60- \\
2.84 \\
0.47- \\
2.36\end{array}$ & $\begin{array}{l}0.22 \\
0.47\end{array}$ \\
\hline \multicolumn{11}{|c|}{ it characteristics } \\
\hline $\begin{array}{l}\text { rroups } \\
: 0-65 \\
>65\end{array}$ & $<40$ years & $\begin{array}{l}1.81 \\
0.28\end{array}$ & $\begin{array}{l}1.30- \\
3.32 \\
0.14- \\
0.62\end{array}$ & $\begin{array}{l}0.04 \\
0.01\end{array}$ & $\begin{array}{l}3.59 \\
0.62\end{array}$ & $\begin{array}{l}1.03- \\
9.54 \\
0.25- \\
1.15\end{array}$ & $\begin{array}{l}0.04 \\
0.19\end{array}$ & $\begin{array}{l}1.32 \\
0.54\end{array}$ & $\begin{array}{l}0.71- \\
3.74 \\
0.28- \\
2.31\end{array}$ & $\begin{array}{l}0.48 \\
0.21\end{array}$ \\
\hline $\begin{array}{l}\text { ational } \\
\text { :rsity } \\
\text { ersity }\end{array}$ & Illiterate & $\begin{array}{l}0.80 \\
0.27\end{array}$ & $\begin{array}{l}0.55- \\
1.05 \\
0.21- \\
0.33\end{array}$ & $\begin{array}{l}0.61 \\
0.01\end{array}$ & $\begin{array}{l}1.06 \\
1.21\end{array}$ & $\begin{array}{l}0.45- \\
2.52 \\
0.58- \\
2.46\end{array}$ & $\begin{array}{l}0.90 \\
0.77\end{array}$ & $\begin{array}{l}1.17 \\
0.37\end{array}$ & $\begin{array}{l}0.52- \\
3.61 \\
0.12- \\
0.66\end{array}$ & $\begin{array}{l}0.89 \\
0.01\end{array}$ \\
\hline of & Urban & 2.66 & $\begin{array}{l}1.45- \\
3.88\end{array}$ & 0.17 & 0.75 & $\begin{array}{l}0.29- \\
1.93\end{array}$ & 0.56 & 0.86 & $\begin{array}{l}0.10- \\
3.15\end{array}$ & 0.90 \\
\hline al status & Married & 1.36 & $\begin{array}{l}0.78- \\
1.94\end{array}$ & 0.80 & 0.36 & $\begin{array}{l}0.10- \\
1.23 \\
\end{array}$ & 0.10 & & - & \\
\hline ehold & $<5$ persons & 0.59 & $\begin{array}{l}0.15- \\
2.28\end{array}$ & 0.45 & 0.75 & $\begin{array}{l}0.32- \\
1.80\end{array}$ & 0.53 & 0.89 & $\begin{array}{l}0.13- \\
2.15\end{array}$ & 0.72 \\
\hline ance & No & 0.66 & $\begin{array}{l}0.28- \\
1.04\end{array}$ & 0.18 & 0.22 & $\begin{array}{l}0.09- \\
0.43\end{array}$ & 0.02 & - & - & - \\
\hline \multicolumn{11}{|c|}{ of household characteristics } \\
\hline roups & $<50$ years & 0.97 & $\begin{array}{l}0.89- \\
1.04\end{array}$ & 0.36 & 0.96 & $\begin{array}{l}0.91- \\
1.00\end{array}$ & 0.07 & 1.07 & $\begin{array}{l}0.94- \\
1.24\end{array}$ & 0.28 \\
\hline $\begin{array}{l}\text { ational } \\
\text { :rsity } \\
\text { ersity }\end{array}$ & Illiterate & $\begin{array}{l}0.94 \\
0.79\end{array}$ & $\begin{array}{l}0.57- \\
1.55 \\
0.45- \\
1.11\end{array}$ & $\begin{array}{l}0.81 \\
0.55\end{array}$ & $\begin{array}{l}0.90 \\
0.77\end{array}$ & $\begin{array}{l}0.64- \\
1.26 \\
0.48- \\
1.06\end{array}$ & $\begin{array}{l}0.53 \\
0.48\end{array}$ & $\begin{array}{l}0.63 \\
0.79\end{array}$ & $\begin{array}{l}0.27- \\
1.53 \\
0.31- \\
1.17\end{array}$ & $\begin{array}{l}0.32 \\
0.09\end{array}$ \\
\hline al status & Married & 2.14 & $\begin{array}{l}0.54- \\
8.54\end{array}$ & 0.28 & 0.56 & $\begin{array}{l}0.25- \\
1.26\end{array}$ & 0.16 & - & - & - \\
\hline
\end{tabular}

Note: Variables of marital statuses and health insurance condition of the patients are omitted due to collinearity problem in improvising payment model.

\section{Discussion}


This cross-sectional study was investigated the OOP payments, catastrophic, and impoverishing health spending attributed to the diseases of breast cancer in Iran. The results indicate that each household with a breast cancer patient pays an average of $\$$ US 97.87 for diagnostic, treatment, and rehabilitation services. It is much lower than the estimated OOP for similar patients in Ontario (\$US 393) [17], the rural of Florida (\$US 253.2) [6], and Nepal (\$US 289.78) [18]. However, our results strongly support the findings of these similar studies that there is a statistically significant difference among SES quintiles in the OOP payments. As the higher quintiles, on average, also have higher OOP payments to receiving the services. $[6,17,18]$

\section{CHE and breast cancer}

Depending on threshold levels of $40 \%, 20 \%$, and $10 \%$ of the household's capacity to pay, the incidences of CHE caused by breast cancer are estimated as $13.77 \%, 27.54 \%$, and $40.58 \%$. It means that in the bestcase scenario, $13.7 \%$ of the Iranian households involved with the disease suffered from CHE and had forced to sacrifices the consumption of other goods and services necessary for their well-being. This is much lower than estimates made by other comparable studies in Iran (60.9\%) [19], China (30.98\%) [20], Ethiopia (72.3\%) [21], Vietnam (71.8\%) [22], Haiti (67\%) [23], and South Korea (39.8\%) [24]. Although households with higher SES levels are less likely to incur CHE, a significant portion of all SES subgroups are exposed to these limiting costs. This amount is estimated for the most affluent segment of society in different scenarios between 10.34 to $41.38 \%$. This result has been more than expected, as these subgroups a smaller portion of their income on the required health care services than others. This unexpected finding could be that the higher SES subgroups receive most of the needed services from the private sector, which their tariffs are far higher than the cost of similar services in the public sector, which often goes to those with lower SES status.

It is interesting to note that those 40-65 years old were 1.81times more likely, and the patients older than 65 were 3.57 times less likely to experience CHE than the younger subgroup. This could be because of their source of services and illness duration. The elderly and middle-aged patients mostly use the cheaper care of public hospitals and expensive care of private clinics, respectively. Besides, unlike middle-aged people, the elderly have a shorter illness duration because of their older age and high mortality rate and therefore incur lower costs. This study also discovered a significant negative association between education level and incidence of $\mathrm{CHE}$, as those with a university degree were 3.7 times less likely to experience $\mathrm{CHE}$ than illiterate people. Besides, the patients who received radiotherapy treatment were more likely to incur $\mathrm{CHE}$ compared with others. These findings support evidence from previous investigations [24-27].

\section{Impoverishing expenditure and breast cancer}

CHE's high incidence has significantly increased the risk of household impoverishment, with $5.07 \%$ of the households being impoverished due to OOP breast cancer payments. Of course, most of these households belonged to the poorer sections of society, so that the incidence of impoverishing health spending in the poorest quintile was equal to $18.52 \%$ and in the richest quintile was equal to zero. 
The yields in this investigation were higher than those of other studies conducted among nationally representative households in Iran, China, and Vietnam [28-30] and lower than cancer patient households of Vietnam [22]. Impoverishment from financing breast cancer care has only had a significant negative relationship with education level. Patients with a university education level were about 2.7 times less likely to become poor than illiterate patients. Further analysis of the data confirmed that most patients with university education level belonged to the high-income subgroup. Thus, the education level was only a confounding variable, and this observed relationship was mainly due to the high level of household income.

The findings must be interpreted in light of this limitation that, as other research on household data, this study also relied on self-reported costs and incomes, subject to recall bias. Thus, it is not excluded that patients forgot, underestimated, or overestimated some of the asked information.

\section{Policy implications}

Clearly, the study results show that Iranian households with breast cancer patients are exposed to high treatment costs and impoverishing health expenditures. Therefore, they should be supported by expanding insurance coverage, governmental supporting programs, and increasing access to quality and effective public sector services. As a result, optimization should be implemented, putting more emphasis on the poor and fragile population. Knowing the source of payment for the treatment of the disease among these households helps us in understanding the financial situation of breast cancer disease in Iran. The study's findings showed that payments were made from various sources, of which current household income and health insurance were the primary sources of payment, but they were not sufficient. More than two-thirds of the households used their savings to finance their medical expenses, and more than a third of them sold their capital goods. Also, about a quarter of them are forced to borrow and about $16 \%$ of them are forced to take a bank loan. (Table 5 ) This finding broadly supports the work of other studies in this area in Iran [19, 31], Ethiopia [21, 32], India [33], and Australia [34].

Table 5. Sources of payment for breast cancer costs among the participants

\begin{tabular}{|l|c|c|c|c|c|c|}
\hline Sources & $\begin{array}{c}\text { Current } \\
\text { income }\end{array}$ & $\begin{array}{c}\text { Health } \\
\text { insurance }\end{array}$ & Saving & $\begin{array}{c}\text { Capital* }^{*} \\
\text { sales }\end{array}$ & Borrowing & $\begin{array}{c}\text { Bank } \\
\text { loans }\end{array}$ \\
\hline Number & 134 & 134 & 93 & 51 & 34 & 22 \\
\hline Percent & 97.10 & 97.10 & 67.39 & 36.96 & 24.64 & 15.94 \\
\hline
\end{tabular}

* Such as stock, gold, home appliances, and other similar cases

\section{Conclusions}

In this cross-sectional investigation, we applied a retrospective reporting of household costs on breast cancer disease management to calculating the OOP, impoverishing, and catastrophic breast cancer expenditure. This study finds that each patient had an average OOP payment of \$US 97.87 for the 
requested services, leading to impoverished of $5.07 \%$ and exposed to $\mathrm{CHE}$ of $13.77 \%$ of their households. These indicators have been mainly concentrated among the poor, as they have spent a large part of their meager income on buying the needed services, and for this purpose, most of them have been forced to sell their assets, borrow, or take a bank loan. Therefore, vulnerable subgroups should be covered by broader insurance coverage and governmental supporting programs.

\section{Abbreviations}

OOP: Out-Of-Pocket

CHE: Catastrophic Health Expenditure

SES: Socio-Economic Status

WHO: World Health Organization

SD: Standard Deviation

Cl: Confidence Interval

\section{Declarations}

\section{Availability of data and materials}

The datasets generated and/or analyzed during the current study are not publicly available for confidentiality reasons since individual privacy could be compromised but are available from the corresponding author on reasonable request.

\section{Acknowledgments}

Not applicable

\section{Funding}

This research was supported by the Deputy of research and technology of Urmia University of Medical Sciences Grant Number IR.UMSU.REC.1398.022.

\section{Author information}

\section{Affiliations}

Department of Health Management and Economics, School of Public Health, Urmia University of Medical Sciences, Urmia, Iran 
Reproductive Health Research Centre, School of Public Health, Urmia University of Medical Sciences, Urmia, Iran

\section{Contributions}

FA and CA conceived the idea of the study, FA, HFE, and CA contributed to the study design, CA performed the statistical analysis, CA, HY, and FA took part in the interpretation of the results and FA, HFE, HY, and CA critically revised manuscript drafts. All authors read and approved the final version of the manuscript.

\section{Corresponding author}

Correspondence to Cyrus Alinia.

\section{Ethics declarations}

\section{Ethics approval and consent to participate}

This study protocol was reviewed by Research Ethics Committee at the Deputy of research and technology, Urmia University of Medical Sciences (IR.UMSU.REC.1398.022) and was found to comply with ethical standards. This study was accordance with the 1964 Helsinki declaration and its later amendments or comparable ethical standards. Also, all participants give written informed consent to participate in this study.

\section{Consent for publication}

Not applicable.

\section{Competing interests}

The authors declare that they have no competing interests.

\section{References}

1. Nafissi N, Khayamzadeh M, Zeinali Z, Pazooki D, Hosseini M, Akbari MEJMEJoC: Epidemiology and histopathology of breast cancer in Iran versus other Middle Eastern countries. 2018, 9(3):243-251.

2. AsghariEbrahimAbad MJ, Kareshki HJJoFUoMS: Psychological Consequences of Breast Cancer in Iran: A Systematic review. 2019, 8(4):986-999.

3. Kazemzadeh S, Babaei EJJoFUoMS: Investigating the expression of CCAT2 gene as a new molecular marker in breast tumors. 2018, 7(4):573-581.

4. Tahergorabi Z, Moodi M, Mesbahzadeh BJJoBUoMS: Breast Cancer: A preventable disease. 2014, 21(2):126-141.

5. Abolghasemi J, Asadi Lari M, Mohammadi M, Salehi MJJoAUoMS: Effective factors in the appearance of metastasis in patients with breast cancer using frailty model. 2013, 15(8):85-94. 
6. Pisu M, Azuero A, Benz R, McNees P, Meneses KJCM: Out-of-pocket costs and burden among rural breast cancer survivors. 2017, 6(3):572-581.

7. Pisu M, Azuero A, McNees P, Burkhardt J, Benz R, Meneses KJJoCS: The out of pocket cost of breast cancer survivors: a review. 2010, 4(3):202-209.

8. Mols F, Tomalin B, Pearce A, Kaambwa B, Koczwara BJSCiC: Financial toxicity and employment status in cancer survivors. A systematic literature review. 2020:1-16.

9. Bazyar M, Pourreza A, Harirchi I, Akbari F, Mahmoudi MJH: Medical and non-medical direct costs of cancers in patients hospitalized in Imam Khomeini cancer institution-2010. 2012, 11(1):39-50.

10. Afkar A, Heydari S, Jalilian H, Pourreza A, Sigaroudi AEJJoCP: Hospitalization costs of breast cancer before and after the implementation of the Health Sector Evolution Plan (HSEP), Iran, 2017: a retrospective single-centre study. 2020:100228.

11. Mehrdad RJJ: Health system in Iran. 2009, 52(1):69-73.

12. Onoka CA, Onwujekwe OE, Hanson K, Uzochukwu BSJTM, Health I: Examining catastrophic health expenditures at variable thresholds using household consumption expenditure diaries. 2011, 16(10):1334-1341.

13. O'donnell O, Van Doorslaer E, Wagstaff A, Lindelow M: Analyzing health equity using household survey data: a guide to techniques and their implementation: The World Bank; 2007.

14. Wagstaff A: Measuring financial protection in health: The World Bank; 2008.

15. Majid Einian MA, Arian Shahbazian, Zahra Kaviani: Estimating the poverty line for the first six months of 2018. In.: Parliam Res Cent Islam Repub; 2018.

16. Council NR: Measuring poverty: A new approach: National Academies Press; 1995.

17. Longo C, Bereza BJCO: A comparative analysis of monthly out-of-pocket costs for patients with breast cancer as compared with other common cancers in Ontario, Canada. 2011, 18(1):e1.

18. Khatiwoda SR, Dhungana RR, Sapkota VP, Singh SJFiPH: Estimating the direct cost of Cancer in Nepal: a cross-sectional study in a tertiary Cancer hospital. 2019, 7:160.

19. Kavosi Z, Delavari H, Keshtkaran A, Setoudehzadeh F: Catastrophic health expenditures and coping strategies in households with cancer patients in Shiraz Namazi hospital. 2014.

20. Zheng A, Duan W, Zhang L, Bao X, Mao X, Luo Z, Jin FJCm: How great is current curative expenditure and catastrophic health expenditure among patients with cancer in China? A research based on "System of Health Account 2011". 2018, 7(8):4036-4043.

21. Kasahun GG, Gebretekle GB, Gecho YH, Woldemariam AA, Fenta TG: Catastrophic Healthcare Expenditure and Coping Strategies among Patients Attending Cancer Treatment Services in Addis Ababa, Ethiopia. 2020.

22. Hoang VM, Pham CP, Vu QM, Ngo TT, Tran DH, Bui D, Pham XD, Tran DK, Mai TKJBri: Household financial burden and poverty impacts of cancer treatment in Vietnam. 2017, 2017.

23. O'Neill KM, Mandigo M, Pyda J, Nazaire Y, Greenberg SL, Gillies R, Damuse RJS: Out-of-pocket expenses incurred by patients obtaining free breast cancer care in Haiti: A pilot study. 2015, 
158(3):747-755.

24. Choi J-W, Cho K-H, Choi Y, Han K-T, Kwon J-A, Park E-C: Changes in economic status of households associated with catastrophic health expenditures for cancer in South Korea. 2014.

25. Su TT, Kouyaté B, Flessa SJBotWHO: Catastrophic household expenditure for health care in a lowincome society: a study from Nouna District, Burkina Faso. 2006, 84:21-27.

26. Song E-C, Shin Y-JJJoPM, Health P: The effect of catastrophic health expenditure on the transition to poverty and the persistence of poverty in South Korea. 2010, 43(5):423-435.

27. Kavosi Z, Rashidian A, Pourreza A, Majdzadeh R, Pourmalek F, Hosseinpour AR, Mohammad K, Arab MJHp, planning: Inequality in household catastrophic health care expenditure in a low-income society of Iran. 2012, 27(7):613-623.

28. Rezapour A, Ghaderi H, Azar F, Larijani B, Gohari MRJLSJ: Effects of health out-of-pocket payment on households in iran; catastrophic and impoverishment: Population based study in Tehran (2012). 2013, 10(3):1457-1469.

29. Zhao Y, Oldenburg B, Mahal A, Lin Y, Tang S, Liu XJTM, Health I: Trends and socio-economic disparities in catastrophic health expenditure and health impoverishment in China: 2010 to 2016. 2020, 25(2):236-247.

30. Van Minh H, Phuong NTK, Saksena P, James CD, Xu KJSs, medicine: Financial burden of household out-of pocket health expenditure in Viet Nam: findings from the National Living Standard Survey 2002-2010. 2013, 96:258-263.

31. Pourreza A, Harirchi I, Bazyar MJEBHP, Management, Economics: Differentiation of out-of-pocket expenditures in cancer patients; a case study in the cancer institute of Iran. 2017, 1(2):65-73.

32. Tolla MT, Norheim OF, Verguet S, Bekele A, Amenu K, Abdisa SG, Johansson KAJBgh: Out-of-pocket expenditures for prevention and treatment of cardiovascular disease in general and specialised cardiac hospitals in Addis Ababa, Ethiopia: a cross-sectional cohort study. 2017, 2(2).

33. Engelgau MM, Karan A, Mahal AJG, health: The economic impact of non-communicable diseases on households in India. 2012, 8(1):9.

34. Economics DA: Financial impacts of breast cancer in Australia. Deliotte. In.; 2017. 